\title{
Employee Performance Measurements at 'Aisyiyah Klaten Hospital using the Human Resources Scorecard approach
}

\author{
Siti Kundariyah*, Heru Kurnianto Tjahjono, Qurratul Aini, Winny Setyonugroho \\ Hospital Management Study Program, Graduate Program, Universitas Muhammadiyah \\ Yogyakarta, Indonesia \\ *corresponding author, e-mail: kund539@gmail.com
}

\section{ARTICLE INFO}

Article history

Received 07/30/21

Revised 10/26/21

Accepted 11/15/21

Keywords

HR Scorecard;

Key Performance Indicator;

Aisyiyah Klaten Hospital

\section{ABSTRACT}

Background: The rapid development of health services is a challenge for hospitals in facing the increasingly open and accessible competition. Good human resource management is needed to increase the productivity of an organization. One of the strategies to increase productivity and improve human resource management is to use an integrated and comprehensive employee performance measurement. This research measured employee performance using the Human Resources Scorecard (HRSC) approach based on several conditions. HRSC is a Balanced Scorecard with a Human Resources (HR) approach where Key Performance Indicators (KPI) are based on 4 (four) perspectives: Financial Perspective, Customer Perspective, Internal Business Process Perspective, and Learning and Growth Perspective. Method: This study used a quantitative approach with a cross-sectional survey research design. Data collection methods included questionnaires, document review, and Consensus Decision Making Group (CDMG). The research population was 256 employees of the 'Aisyiyah Hospital Klaten. Samples were determined using non-probability sampling technique with a purposive sampling method of 100 respondents. Results: The results showed that overall employee performance was good, with a score of 4.03. Based on Key Performance Indicators for each perspective, the internal business process perspective of employee performance was very good, with a score of 1.24. The financial perspective of employee performance was good with a score of 0.8 , while the customer perspective of employee performance was good, with a score of 1.19 . Finally, the learning and growth perspective of employee performance was good, with a score of 0.8 . Conclusion: With the HRSC approach, the overall performance results of the 'Aisyiyah Klaten Hospital employees were good.

This is an open access article under the CC-BY-SA license.

\section{Introduction}

The current rapid development in the health industry has resulted in increasingly fierce competition. Hence, healthcare companies must improve their performance in a comprehensive and integrated manner to win the competition by improving the quality of work. A company or organization will always face the challenge to survive the competition. Therefore, companies and organizations must run their business dynamically. They also need to be customer-oriented and cost-efficient so they can face changes and competition [1].

Healthcare companies or community service organizations, especially hospitals, are experiencing rapid growth. There are new hospitals, either public or private hospitals with better models and facilities emerging in some regions. The community now has more choices in health services. This development has resulted in an increasingly tough competition. Thus, it is 
important for hospital managers to make improvements and developments through their organizational strategies. In addition, there are some essential points to consider, namely the organization's manner in conducting its activities, the strategies to survive successfully, and the strategies to mobilize and satisfy all interested parties for organizational goals [2].

Human Resources (HR) is one of the most critical assets in maintaining and developing the viability of an organization [3]. A key to the success of the organization's performance in realizing its vision and mission is employee performance. If employees are able to deliver excellent performance, the performance of the organization or company will also be satisfying. Performance can be determined if the individual or group has predetermined success criteria. HR performance of an organization or company is measured based on the employees' competence or the performance of each HR within the organization. Some organizations still measure their HR performance qualitatively and have not considered HR's contribution to strategies and company goals. A reasonable, measurable, and comprehensive HR performance appraisal system will reflect the actual performance of employees. The performance results obtained will give an idea of the role of employees in carrying out the hospital's vision and mission. Moreover, it can also provide an insight on the role of HR development in achieving the organization's shared vision and mission. Comprehensive and measurable employee performance results significantly affect the success of hospital performance.

"Balanced Scorecard" is one of the tools used to measure institutional performance. In the current development where organizations are more dominated by "human capital" and "intangible" capital, the "Human Resources Scorecard" (HRSC) method was developed where this method used specific stages to regulate human resource strategies [5]. A concept to measure HR's contribution is to use the HRSC method [4]. The HRSC transforms the vision, mission, and strategy to become human resources whose contribution can be measured. The HRSC can help managers or leaders of organizations or companies to ensure that all HR decisions support or contribute to business strategies.

There are four perspectives in HRSC: financial perspective, customer perspective, business process perspective, and learning and growth perspective [6]. First, the financial perspective provides a brief insight on the impact of an organization's economic policy and activities. Financial performance helps an organization to evaluate their regulations and its impact on the company's revenue. Second, from the customer perspective, employee achievement is an asset used to implement HR tactics. Therefore, it is necessary to measure employees 'satisfaction regarding rewards and compensation according to the standards set. Third, the business process perspective focuses on company activities that impact customer satisfaction and the organization's financial targets. This perspective focuses on activities within the company that have an impact on achieving company goals and includes a continuous change in processes and services. Fourth, the learning and growth perspective focuses on the system and how to improve the capabilities of human resources, for example, through certification or employee skills development. This perspective focuses on systems and ways to improve human resource capabilities through training and skills development [4].

There are several studies that have conducted research on HRSC by analyzing the four perspectives. One study took the form of qualitative research, and the results showed that the hospital's performance scored $78 \%$. There were three perspectives that should be considered, namely customer, the learning and growth, and the internal business process [1].

The 'Aisyiyah Klaten Hospital has determined its vision and mission. This vision and mission become the guideline for all work units at all levels in carrying out their duties. Hence, all activities must be conducted according to the organization's goals. The hospital's vision is to realize a hospital of exceptional choice for mothers and children. A hospital who not only provides excellent service but also holds Islamic values. One of its missions is to provide professional health services with quality human resources as an effort to serve the community and spread Islamic values. This study measured and analyzed employee performance based on the HRS of 'Aisyiyah Klaten Hospital. The findings contribute to taking the next strategic steps to realize the hospital's vision, mission, and development. In addition, employee performance measurement is necessary for the hospital to manage their strategic responsibilities effectively in facing future competition. This can help the hospital to achieve the vision and mission.

\section{Method}

This research used a quantitative approach and a cross-sectional survey. Each research subject was observed only once. The measurements were made on the status of the character or 
subject variable at the time of examination [16]. The population used in this study was all 256 employees of the 'Aisyiyah Hospital Klaten. Some of the inclusion criteria included: 1) working as nurses and midwives; 2) has worked for more than two years. Respondents who have worked for two years or less at the time of data collection were excluded. Based on the consideration of the selected sample with purposive sampling technique, the total respondents were 100 hospital employees.

The data collection method used to obtain data in this study was a questionnaire and CDMG. HRSC perspective was measured using a questionnaire consisting of 28 questions. All survey questions utilized Likert scale with five answer options, namely: Strongly Disagree (STS) with a value of 1 , Disagree (TS) with a value of 2, Neutral (N) with a value of 3, Agree (S) with a value of 4, and Strongly Agree (SS) with a score of 5. Consensus Decision-Making Group (CDMG) is a decision-making process that involves more than one decision-maker in a group. The CDMG involved the management of the 'Aisyiyah Klaten hospital. Using CDMG, a mutual agreement is obtained to determine a weighting value to the Key Performance Indicator (KPI) from each perspective and provide a weighting perspective in the HRSC method. The research data were analyzed using descriptive statistics with a significance level of $95 \%$.

\section{Results and Discussion}

\subsection{Results}

\subsubsection{Respondents' Characteristics}

Table 1 illustrates that all respondents are women (100\%). More than half of the respondents $(51 \%)$ are between the ages of 30-40 years. In terms of education, most of the respondents had Diploma $3(96 \%)$. Nurses made up nearly three quarters $(72 \%)$ of the total respondents, and the majority of respondents work in inpatient ward B (25\%). Regarding employee status and working period, a significant number of respondents were permanent employees (47\%) and have worked for $10-20$ years $(75 \%)$.

Table 1. Respondents Characteristics ( $\mathrm{N}=100)$

\begin{tabular}{lc}
\hline \multicolumn{1}{c}{ Variable } & $\mathbf{n}, \%$ \\
\hline Age & 21 \\
$<30$ years old & 51 \\
30 - 40 years old & 28 \\
40 - 50 years old & \\
Education & 96 \\
Diploma (D3) & 4 \\
Bachelor Degree (S1) & \\
Occupation & 28 \\
Midwife & 72 \\
Nurse & \\
Working Unit & 22 \\
Emergency Room & 17 \\
Operating Room & 9 \\
Birthing Room & 17 \\
Ward A & 25 \\
Ward B & 10 \\
Intensive Care Unit Room & \\
Working Period & 8 \\
2-5 years & 34 \\
5-10 years & 47 \\
10-20 years & 11 \\
>20 years & \\
Employee Status & 75 \\
Permanent & 25 \\
Temporary & \\
\hline
\end{tabular}




\subsubsection{Results of $K P I$}

Based on Table 2, the overall KPI achievement of RSIA 'Aisyiyah Klaten Hospital is 4.03. The KPI achievements for each perspective are as follows: financial perspective with a weight of 0.2 is 0.8 , customer perspective with a weight of 0.3 is 1.19 , internal business process perspective with a weight of 0.3 is 1.24 , learning and growth perspective with a weight of 0.2 is 0.8 .

\section{Table 2. KPI Results at 'Aisyiyah Hospital Klaten}

\begin{tabular}{|c|c|c|c|c|}
\hline Performance Goals & KPI & Weight & Score & $\begin{array}{l}\text { Weighted } \\
\text { Score }\end{array}$ \\
\hline \multicolumn{5}{|l|}{ Financial Perspective } \\
\hline \multirow{3}{*}{ Training Cost Effectiveness } & Employees' skills increase after attending the training provided by the hospital & 0.04 & 4.26 & 0.17 \\
\hline & The hospital allows sharing skills for every knowledge investment provided. & 0.03 & 4.11 & 0.12 \\
\hline & The training budget provided by the hospital will increase the hospital's revenue. & 0.03 & 3.85 & 0.12 \\
\hline \multirow[t]{4}{*}{ Cost of Revenue } & Job satisfaction can increase work productivity. & 0.03 & 4.07 & 0.12 \\
\hline & Performance results contribute to increasing hospital revenues. & 0.04 & 4.07 & 0.16 \\
\hline & Salary increases as hospital revenue increases. & 0.03 & 3.8 & 0.11 \\
\hline & Subtotal KPI & 0.2 & & 0.8 \\
\hline \multicolumn{5}{|l|}{ Customer Perspective } \\
\hline \multirow[t]{2}{*}{ Compensation } & Employees get proper compensation from the hospital. & 0.04 & 3.69 & 0.15 \\
\hline & Employees can complete the work correctly and quickly. & 0.04 & 3.54 & 0.14 \\
\hline \multirow[t]{3}{*}{ Competence } & Employees get recognition for their work achievements. & 0.04 & 4.04 & 0.16 \\
\hline & Employees have reliable knowledge and skills in handling patients. & 0.04 & 3.92 & 0.16 \\
\hline & Employees can cooperate with co-workers and support each other. & 0.04 & 4.31 & 0.17 \\
\hline Career path & I am proud of my job & 0.04 & 3.77 & 0.15 \\
\hline \multirow[t]{3}{*}{ Pride } & The work environment has a positive influence. & 0.03 & 4.26 & 0.13 \\
\hline & Hospitals provide opportunities for career advancement. & 0.03 & 4.23 & 0.13 \\
\hline & Subtotal KPI & 0.3 & & 1.19 \\
\hline \multicolumn{5}{|c|}{ Internal Business Process Perspective } \\
\hline \multirow[t]{2}{*}{ Work environment } & The facilities provided make it easier to complete the work. & 0.04 & 3.92 & 0.16 \\
\hline & Patients are treated according to applicable procedures. & 0.04 & 3.89 & 0.16 \\
\hline \multirow[t]{4}{*}{ Work procedures } & All tasks assigned by the hospital can be carried out correctly. & 0.05 & 4.43 & 0.22 \\
\hline & Hospitals provide good job security for employees & 0.05 & 4.14 & 0.21 \\
\hline & The hospital has made a clear SOP for the primary duties and functions of employees. & 0.04 & 4.04 & 0.16 \\
\hline & Employees provide an excellent explanation to the patient/patient's family every time they apply a procedure. & 0.04 & 4.37 & 0.17 \\
\hline \multirow[t]{2}{*}{ Service Quality } & Employees prioritize quality over quantity in providing services to patients. & 0.04 & 3.94 & 0.16 \\
\hline & Subtotal KPI & 0.3 & & 1.24 \\
\hline \multirow{5}{*}{$\begin{array}{l}\text { Learning and Growth Perspective } \\
\text { HR training and development }\end{array}$} & & & & \\
\hline & Employees attend training that supports their performance improvement. & 0.03 & 4.13 & 0.12 \\
\hline & $\begin{array}{l}\text { The hospital provides complete facility support in carrying out the duties and responsibilities assigned to } \\
\text { employees. }\end{array}$ & 0.03 & 3.35 & 0.12 \\
\hline & Employees need to update their knowledge and skills from time to time. & 0.03 & 4.24 & 0.13 \\
\hline & Employees can develop and improve their abilities optimally while working. & 0.03 & 4.08 & 0.12 \\
\hline Management Information System & The hospital organizes participation in activities. & 0.02 & 4.01 & 0.08 \\
\hline \multirow[t]{4}{*}{ HR Engagement } & Hospitals provide easy access to data and information & 0.03 & 4.1 & 0.12 \\
\hline & Employees are often involved in activities carried out by the hospital. & 0.03 & 3.52 & 0.11 \\
\hline & Subtotal KPI & 0.2 & & 0.80 \\
\hline & Total KPI & 1 & & 4.03 \\
\hline
\end{tabular}




\subsection{Discussion}

The Human Resource Scorecard (HRSC) method showed that the overall employee performance was good. The management must maintain these performance results and strive to improve the performance to the best result by increasing the achievements of the four HRSC perspectives. Each performance result can be seen from the measured scores of the four HRSC perspectives.

From a financial perspective, the performance targets are the training costs and income costs effectiveness. This perspective is also related to the cost of HR and the contribution of HR to the company. One of the contributions that HR can provide is to develop employees' skills which can be realized through training. Training is a means to build human resources towards globalization full of challenges. Therefore, training activities are needed to face the increasingly fierce competition. Furthermore, employees must also develop their competencies according to the science and technology development [20].

In addition, training for companies improves the effectiveness and quality of employees at work, which will ultimately increase the company's revenue. Therefore, the status of employees in the modern management era becomes a critical asset [21-22]. The training program will increase the efficiency and effectiveness of employees' work in achieving the work targets. Training will also strengthen the attitude and spirit of customer-oriented service. In addition to training, another performance target from a financial perspective is hospital revenue. According to a study, HR performance is measured by employee productivity. The increase in hospital revenue is strongly influenced by employee performance. The better the employee's performance is, the better hospital's revenue will be [22].

The result of the financial perspective performance scores in this study is quite satisfying. The management needs to maintain and improve the performance of HR from a financial perspective to get the maximum achievement. Hospital management must realize that employees are hospital assets that will determine success in achieving the hospital's vision and mission. For this reason, hospitals need to improve employees competence through training that improves employee skills. Management should also be aware that the hospital budget spent on employee training is an investment to increase hospital revenue.

With a score of 3.85 , the management needs to pay attention to the budget training because it is the second-lowest score in the financial perspective The training budget needs to be increased so that the training can run more effectively and lead to the increase of hospital productivity and revenue. From the results of the financial perspective questionnaire, employee income got the lowest score of 3.8. Although the score is actually quite high, it is still the lowest score from the financial perspective. Therefore, the management should pay more attention to the employee pay. Employee income should increase along with the hospital revenue while still considering operational costs and investment costs.

Although the score from the financial perspective was good, hospital management should improve employee performance. For example, they can periodically hold or involve employees in training and conducting performance evaluations. Thus, the skills possessed can contribute to hospital income. These findings are similar to that of a study which reported that the cost of training services provided to nurses contributed to a revenue increase at the Royal Prima Hospital in Medan [1]. Furthermore, the findings of a study conducted at the Bhayangkara Tebing Tinggi hospital concluded that driven by the performance of its human resources, the employee performance as well as the revenue increased after attending training. This means that the findings of this study are consistent with those of previous studies [11].

From the customer perspective, the targets for employee performance are employee satisfaction, competence, career path, and pride. Employee satisfaction depends on the suitability or balance between expectation and reality. Each individual has a different level of satisfaction according to the value system [23]. The satisfaction is measured based on the fact faced and accepted as compensation for the effort given. Competence refers to the ability to do a job based on skills and knowledge which is supported by the work attitude required [23]. The result showed that customer perspective scored 1.19. This means that it can be categorized as good although it has not yet reached the maximum result. These results need to be maintained and improved to achieve the maximum result by looking at the scores of each indicator from the customer perspective.

The respondents' answers to the questionnaire on customer perspective revealed that most scores were high. The lowest score that requires attention from management is the indicator of recognition of employee performance with a score of 3.54. This score is in the high category but is the lowest score from the customer perspective. Thus, it needs improvement to 
achieve an optimal level of employee satisfaction It can be a system of recognition, promotion, or other rewards. These findings match those of earlier studies which showed that employee performance based on the customer perspective was good. A higher score obtained from the customer's perspective would further increase hospital revenue [1-11].

The internal business process perspective focuses on internal processes that impact employee satisfaction and achieve the organization's financial goals. The performance targets of this perspective include the work environment, work procedures, and service quality. The internal business process perspective scored 1.24 and can be categorized as very good. These results need to be maintained and improved to achieve the maximum result by increasing the value of indicators from the internal business process perspective.

Based on the respondents' answers to the questionnaire, job security for employees scored 3.89. The score is high, but it is the lowest score from this perspective. Management needs to pay more attention to employee safety, provide more comprehensive facilities and infrastructure, and conduct a health check to employees regularly. These efforts should be conducted so that the hospital's K3 program can run effectively. Contrary to these findings, earlier studies showed that better facilities did not contribute tonurses' performance as expected by hospital management [1]. However, one study reported that this perspective influenced employee satisfaction and hospital financial improvement [11].

The learning and growth perspective focuses on systems and strategies for human resource development, such as training, employee involvement in activities that support hospital programs to realize organizational goals, and support for hospital management information systems. Training refers to non formal all employee competency improvement activities within and outside hospitals. Training is a critical element in employee development. The activities held are intended to assist employees in developing their capacity and abilities to work according to their competencies. Thus, performance improvements can be achieved and the organization's general goals can be realized.

Hospital Management Information System (MIS) is an arrangement that deals with data collection, information presentation, analysis and inference of information, and the delivery of information needed for hospital activities [24]. Integration of information is an essential element in hospital management. Integrated information allows planning, control, and supervision properly, quickly, and directly. Operational tasks can be more effective and efficient and increase the speed and accuracy of delivering information to management by utilizing a computer program to manage hospital information systems. A suitable information system will play a critical role in the decision-making process by hospital leaders and strategic facilities in providing customer satisfaction-oriented services [25]. Another performance target from a learning and growth perspective is employee engagement. Employee involvement in various hospital activities will lead to good relations with employees-the more employees involved in hospital activities, the more significant the role of employees in achieving organizational goals [26-28].

This study indicated that employee performance is good as seen from the score of 0.8 . However, the hospital management still needs to maintain these results and improve their performance to get the maximum result by increasing the indicator value in the learning and growth perspective. From the score of respondents' answers to the questionnaire, the lowest score was employees' involvement in hospital activities, at 3.52. This result was high but was the lowest according to the learning and growth perspective. The hospital management needs to involve employees more often in hospital activities so that a more optimal working relationship between management and employees can be established and organizational goals can be achieved together. These results are different from that of a study which reported that all indicators of this perspective have achieved the maximum results $[1,29]$. However, some studies revealed that all indicators of this perspective have not shown the maximum results $[11,30]$.

\section{Conclusion}

Using the HRSC approach, the overall performance results of the 'Aisyiyah Klaten Hospital employees were good. However, the hospital needs to maintain the performance value achieved and improve employee performance to obtain the maximum result. Monitoring and evaluating employee performance should be conducted regularly to assess the progress of employee performance results. Although the results from all perspectives were good or even very good, more attention is required from hospitals to the indicators with the lowest scores in 
each perspective. It is necessary to formulate related policies to improve employee performance so that the results of performance appraisals can be maximized.

\section{Declaration}

Conflict of Interest: We have no conflicts of interest to disclose in this study.

Acknowledgments: We would like to express our gratitude to the University of Muhammadiyah Yogyakarta (UMY) for funding the scientific publication of this study.

\section{References}

1. Löffler K, Goldgruber J, Hartinger G. Moving Towards a Competence Centre for Geriatric Medicine and Care: Quality Management and Human Resource Management as Major Support Factors. Best Pract Res Clin Anaesthesiol. 2018 Mar;32(1):47-55. doi: 10.1016/j.bpa.2018.04.003. Epub 2018 Apr 14. PMID: 30049338.

2. Wicaksana dan Aini. a Private Hospital'S Swot Analysis As an Accreditation Preparation Strategy. Turkish J Physiother Rehabil. 2021;32(3):518-27.

3. Bekbergenova Z, Derbissalina G, Umbetzhanova A, Koikov V. [Key Indicators of Performance as a Method for Monitoring Nursing Service]. Georgian Med News. 2020 Feb;(299):151-157. Russian. PMID: 32242864.

4. Pongpirul K, Kanjanabuch T, Puapatanakul P, Chuengsaman P, Dandecha P, Kingwatanakul P, Sritippayawan S, Chittinandana A, Eiam-Ong S, Vareesangthip K, Tungsanga K; Steering Committee, Advisory Board of CAPD, the Nephrology Society of Thailand. National feasibility survey of peritoneal dialysis key performance indicators in Thailand from provider perspective. Nephrology (Carlton). 2020 Jun;25(6):483-490. doi: 10.1111/nep.13668. Epub 2019 Oct 20. PMID: 31577374.

5. Lima TM, Aguiar PM, Storpirtis S. Development and Validation of Key Performance Indicators for Medication Management Services Provided for Outpatients. Res Social Adm Pharm. 2019 Sep;15(9):1080-1087. doi: 10.1016/j.sapharm.2018.09.010. Epub 2018 Sep 22. PMID: 30262211.

6. Shawahna R. Development of Key Performance Indicators to Capture in Measuring the Impact of Pharmacists in Caring for Patients with Epilepsy in Primary Healthcare: A Delphi Consensual Study. Epilepsy Behav. 2019 Sep;98(Pt A):129-138. doi: 10.1016/j.yebeh.2019.07.034. Epub 2019 Jul 30. PMID: 31374468.

7. Baird KM, Tung A, Yu Y. Employee Organizational Commitment and Hospital Performance. Health Care Manage Rev. 2019 Jul/Sep;44(3):206-215. doi: 10.1097/HMR.0000000000000181. PMID: 28915165.

8. Mogensen KM, Bouma S, Haney A, Vanek VW, Malone A, Quraishi SA, Guenter P. Hospital Nutrition Assessment Practice 2016 Survey. Nutr Clin Pract. 2018 Oct;33(5):711-717. doi: 10.1002/ncp.10179. Epub 2018 Aug 8. PMID: 30088829.

9. Abraham J, Hirt J, Kamm F, Möhler R. Interventions to Reduce Physical Restraints in General Hospital Settings: A Scoping Review of Components and Characteristics. J Clin Nurs. 2020 Sep;29(17-18):3183-3200. doi: 10.1111/jocn.15381. Epub 2020 Jul 6. PMID: 32558091.

10. Jourdan JP, Muzard A, Goyer I, Ollivier Y, Oulkhouir Y, Henri P, Parienti JJ, Breuil C. Impact of Pharmacist Interventions on Clinical Outcome and Cost Avoidance in A University Teaching Hospital. Int J Clin Pharm. 2018 Dec;40(6):1474-1481. doi: 10.1007/s11096-018-0733-6. Epub 2018 Oct 26. PMID: 30367375.

11. Glette MK, Røise O, Kringeland T, Churruca K, Braithwaite J, Wiig S. Nursing Home Leaders' and Nurses' Experiences of Resources, Staffing and Competence Levels and the Relation to Hospital Readmissions - A Case Study. BMC Health Serv Res. 2018 Dec 12;18(1):955. doi: 10.1186/s12913-018-3769-3. PMID: 30541632; PMCID: PMC6292004.

12. Oliveira HC, Rodrigues LL, Craig R. Bureaucracy and the Balanced Scorecard in Health Care Settings. Int J Health Care Qual Assur. 2020 Apr 8;ahead-of-print(ahead-of-print). doi: 10.1108/IJHCQA-07-2019-0121. PMID: 32255278.

13. Martunis A, Dalimunthe R, Amalia K, Juanita J, Syahputra H, Adam M, et al. Adaptation of the Balanced Scorecard Model to Measure Performance of the Departments at Dr Zainoel Abidin Regional General Hospital, Banda Aceh. J Model Manag. 2020;15(2):365-79.

14. Rahimi H, Bahmaei J, Shojaei P, Kavosi Z, Khavasi M. Developing a Strategy Map to Improve Public Hospitals Performance with Balanced Scorecard and Dematel Approach. Shiraz E Med J. 2018;19(7).

16. Alvarez L, Soler A, Guiñón L, Mira A. A Balanced Scorecard for Assessing a Strategic Plan in 
A Clinical Laboratory. Biochem Med (Zagreb). 2019 Jun 15;29(2):020601. doi: 10.11613/BM.2019.020601. Epub 2019 Apr 15. PMID: 31015782; PMCID: PMC6457917.

17. Fatima T, Elbanna S. Balanced Scorecard in the Hospitality and Tourism Industry: Past, Present and Future. Int J Hosp Manag. 2020 Oct;91:102656. doi: 10.1016/j.ijhm.2020.102656. Epub 2020 Aug 30. PMID: 32904633; PMCID: PMC7456592.

18. Harvey HB, Sotardi ST. Key Performance Indicators and the Balanced Scorecard. J Am Coll Radiol. 2018 Jul;15(7):1000-1001. doi: 10.1016/j.jacr.2018.04.006. Epub 2018 May 31. PMID: 29861122.

19. Manolitzas P, Grigoroudis E, Christodoulou J, Matsatsinis N. S-MEDUTA: Combining Balanced Scorecard with Simulation and MCDA Techniques for the Evaluation of the Strategic Performance of an Emergency Department. Adv Exp Med Biol. 2020;1194:1-22. doi: 10.1007/978-3-030-32622-7_1. PMID: 32468519.

20. Gao H, Chen H, Feng J, Qin X, Wang X, Liang S, Zhao J, Feng Q. Balanced Scorecard-Based Performance Evaluation of Chinese County Hospitals in Underdeveloped Areas. J Int Med Res. 2018 May;46(5):1947-1962. doi: 10.1177/0300060518757606. Epub 2018 Mar 22. PMID: $29562812 ;$ PMCID: PMC5991253.

21. Wu X, Li S, Xu N, Wu D, Zhang X. Establishing a Balanced Scorecard Measurement System for Integrated Care Organizations in China. Int J Health Plann Manage. 2019 Apr;34(2):672692. doi: 10.1002/hpm.2726. Epub 2019 Jan 7. PMID: 30615222.

22. Al-Kaabi SK, Chehab MA, Selim N. The Balanced Scorecard as a Performance Management Tool in the Healthcare Sector - The Case of the Medical Commission Department at the Ministry of Public Health, Qatar. Cureus. 2019 Jul 29;11(7):e5262. doi: 10.7759/cureus.5262. PMID: 31576255; PMCID: PMC6764650.

23. Hwang YS, Lee TW. Development of Performance Indicators for Clinical Research Coordinators Using the Balanced Scorecard in South Korea. Ther Innov Regul Sci. 2020 May;54(3):618-625. doi: 10.1007/s43441-019-00095-1. Epub 2020 Jan 6. PMID: 33301142.

24. Rouis S, Ben Abdelaziz A, Nouira H, Khelil M, Zoghlami C, Ben Abdelaziz A. Development of a Balanced Scorecard for the Monitoring of Hospital Performance in the Countries of the Greater Maghreb. Systematic Review. Tunis Med. 2018 Oct-Nov;96(10-11):774-788. PMID: 30746671.

25. Sarraf F, Nejad SH. Improving Performance Evaluation Based on Balanced Scorecard with Grey Relational Analysis and Data Envelopment Analysis Approaches: Case Study in Water and Wastewater Companies. Eval Program Plann. 2020 Apr;79:101762. doi: 10.1016/j.evalprogplan.2019.101762. Epub 2019 Nov 24. PMID: 31835153.

26. Aujirapongpan S, Meesook K, Theinsathid P, Maneechot C. Performance Evaluation of Community Hospitals in Thailand: An Analysis Based on the Balanced Scorecard Concept. Iran J Public Health. 2020 May;49(5):906-913. PMID: 32953678; PMCID: PMC7475617.

27. Hwang YS, Lee TW. Development of Performance Indicators for Clinical Research Coordinators Using the Balanced Scorecard in South Korea. Ther Innov Regul Sci. 2019 Aug 28:2168479019870755. doi: 10.1177/2168479019870755. Epub ahead of print. PMID: 31462077.

28. Yang $\mathrm{CH}$, Lee KC. Developing a Strategy Map for Forensic Accounting with Fraud Risk Management: An Integrated Balanced Scorecard-Based Decision Model. Eval Program Plann. 2020 Jun;80:101780. doi: 10.1016/j.evalprogplan.2020.101780. Epub 2020 Feb 7. PMID: 32044113.

29. Behrouzi F, Ma'aram A. Identification and Ranking of Specific Balanced Scorecard Performance Measures for Hospitals: A Case Study of Private Hospitals in the Klang Valley Area, Malaysia. Int $J$ Health Plann Manage. 2019 Oct;34(4):1364-1376. doi: 10.1002/hpm.2799. Epub 2019 Apr 26. PMID: 31025447.

30. Bartolomé-Benito E, Jiménez-Carramiñana J, Sánchez-Perruca L, Bartolomé-Casado MS, Dominguez-Mandueño AB, Marti-Argandoña M, Hernández-Pascual M, Miquel-Gómez A. Desarrollo y evolución de un cuadro de mando integral en atención primaria: lecciones aprendidas [Development and evolution of a balanced scorecard in primary health care: Lessons learned]. Rev Calid Asist. 2017 Jan-Feb;32(1):40-49. Spanish. doi: 10.1016/j.cali.2016.04.005. Epub 2016 Jun 3. PMID: 2726887 